\title{
The Permanent Committee \\ for the International Congresses of Human Genetics
}

On the occasion of the Third International Congress of Human Genetics the Permanent Committee for the International Congresses of Human Genetics met at the University of Chicago's Center for Continuing Education, on Sunday, September $4^{\text {th }}$, 1966 .

The following members of the Committee were present:

A. Franceschetti, L. Gedda, S. G. Geerts, G. Anders, P. E. Becker, J. Böök, J. François, J. Neel, G. Stern, A. Steinberg.

M. Milani-Comparetti was secretary to the meeting. Professor Franceschetti took the chair as Vice-Chairman and briefly commemorated the late Chairman, Prof. F. J. Kallmann.

Prof. Gedda, as Secretary General, reported on the activities intervened between the Congresses of Rome and of Chicago, and asked the Assistant Secretary, M. MilaniComparetti, to report on the draft of the Statutes that had already been sent to each member of the Committee.

Several changes were suggested, resulting in a final text to be submitted to the Congress for adoption during the Business Meeting.

The Statutes provided for delimitation of geographical areas and for nominations of representatives thereof by the Permanent Committee, but since it was impossible at the time to take the necessary preliminary steps, the Committee voted to submit to the Congress a slate of candidates composed of all outgoing members plus Professor Klein for Switzerland.

At Professor Geerts' request it was reaffirmed that, as originally agreed at Montreal in 1958, the International Congresses of Human Genetics would be held every five years, alternating with the International Congresses of Genetics, in which Human Geneticists would continue to participate. Continued cooperation in the planning of the two series of Congresses would, in fact, be assured through Article 2 of the Statutes. 


\section{Third International Congress of Human Genetics Minutes of the Business Meeting September 10, 1966}

I. The meeting was called to order by the President of the Congress, L. Penrose.

2. A draft of the Statutes of the Permanent Committee for the International Congresses of Human Genetics was introduced by Professor Gedda. After some discussion from the floor the draft was unanimously accepted as amended. A copy of the Statutes as amended is included as part of these minutes.

3. A slate of members of the permanent committee was nominated by Professor Franceschetti and seconded. After discussion from the floor nominations were closed and the slate elected by a show of hands. The list of those elected is appended as part of these minutes.

4. A resolution of formal thanks to the City of Chicago, to the University of Chicago and to the Local Committee for their hospitality and help in organizing the meeting was proposed and unanimously passed.

5. The Congress was adjourned at approximately I I :45 A. M.

\section{Statutes of the Permanent Committee for the International Congresses of Human Genetics as Adopted}

I. The Permanent Committee for the International Congresses of Human Genetics is to be elected by the International Congresses of Human Genetics and hold office from the day of election until replaced at the next Congress.

2. The President and Chairman of the Organizing Committee of the last Congress and the current President of the Genetics section of the International Union of Biological Sciences shall be ex-officio members of the Permanent Committee.

2a. (Temporary clause) Ex-officio members of the Committee elected at Rome shall be ex-officio members of the Permanent Committee.

3. The incoming Permanent Committee will appoint a Chairman, two ViceChairmen and a General Secretary.

4. The incoming Committee shall consist of the ex-officio members and a number of elected members proposed by the outgoing Committee on the basis of geographical grouping and of the number of professional human geneticists.

5. Before the next Congress, the Secretary General of the outgoing Committee should contact the Human Genetics Society (or Societies) of each area or, if none, the local Genetics Society (or Societies) or other representative bodies, requesting that a nomination be submitted for consideration at the next Congress.

An unrepresented area that desires representation may apply to the Secretary of the Permanent Committee who will bring the matter up for decision by majority vote of the Permanent Committee. 
6. Should one area fail to nominate (or to agree on a nomination of) a candidate, the Committee can choose to leave the seat vacant or to request the President of the Congress to convene a Nominating Committee which will report to the Congress.

7. Vacancies in the elective membership of the Committee between Congresses will be filled by the Committee itself on the basis of nominations submitted or indicated (under 5).

8. The site of the next Congress should be chosen by common agreement between the representatives of the different geographical areas. If an agreement is not possible the choice is to be made by a secret majority vote of the geographical representatives. Upon the selection of the site for the next Congress, the Chairman of the Organizing Committee thereof will be asked to attend the meetings of the Permanent Committee.

9. Representatives of the World Health Organization and of the Council for the International Organizations of Medical Sciences will be requested to attend the meetings of the Permanent Committee as Observers.

\section{Members elected to the Permanent Committee}
G. Anders
P. E. Becker
J. A. Böök
J. François
F. C. Fraser
N. Freire-Maia
D. Klein
M. Lamy
F. Mainx
A. Nakajima
J. V. Neel
C. Stern
A. C. Stevenson

\author{
Holland \\ Germany \\ Scandinavia \\ Belgium \\ Canada \\ Latin America \\ Switzerland \\ France \\ Austria \\ Japan \\ United States \\ United States \\ Great Britain
}

Ex-officio members of the Permanent Committee:
A. Franceschetti
L. Gedda
S. J. Geerts
L. S. Penrose
A. G. Steinberg 
The newly-elected Permanent Committee held its first meeting at the University of Chicago's Center for Continuing Education immediately after the end of the Third International Congress.

The meeting was attended by the following members:
A. Franceschetti
L. Gedda
L. S. Penrose
S. G. Geerts
G. Anders
P. E. Becker
J. Böök
J. François
M. Lamy
A. Nakajima
J. Neel
C. Stern
A. Steinberg

By unanimous votes the Committee elected Professor A. Franceschetti to be its Chairman and confirmed Professor Luigi Gedda as Secretary General, with M. Milani-Comparetti as Assistant Secretary. While Prof. F. Clarke Fraser remained Vice-Chairman, the election of the second Vice-Chairman was postponed.

The Committee was informed by the Secretary General that preliminary invitations had been received from Brussels, Edinburgh and Paris for the organization of the Fourth International Congress of Human Genetics. There followed a discussion as to whether the Committee should vote at once on the three proposed sites. The matter was put to a vote by the Chairman, and the majority voted to postpone the decision. In the meantime the Secretary General would request further information from the three cities. It was decided that, in addition to a formal invitation by the local University, the Secretary General should seek information on the following points:

- Availability of convenient accommodation.

- Availability of travel and/or accommodation grants for foreign participants.

- Possibility of providing simultaneous translation (if only for the main sessions and Symposia). Proceedings.

Such information, to be obtained at the earliest possible date, would be circulated to the members of the Committee for their consideration. A decision would be taken either by mail or during a later meeting.

Professor Nakajima suggested that a meeting of the Committee be planned on the occasion of the XII International Congress of Genetics, to be held in Tokyo in 1968. 